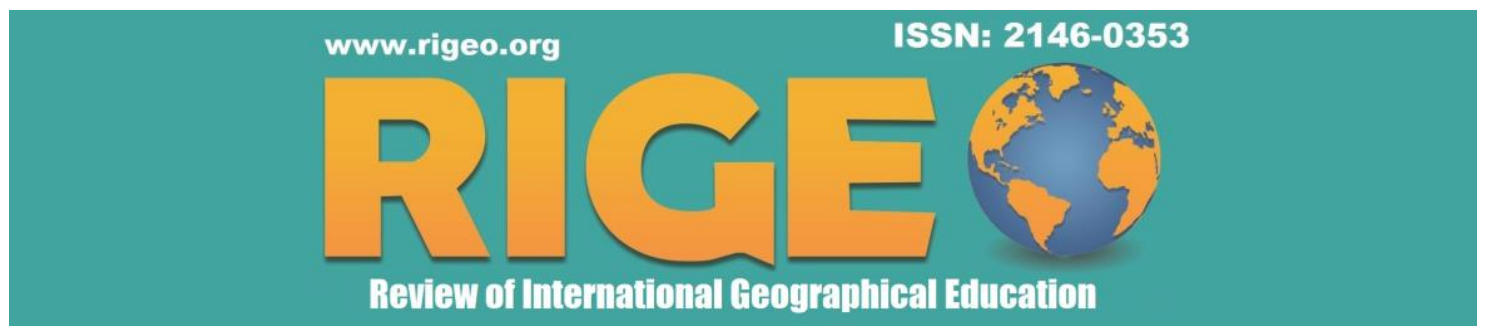

(C) RIGEO, Volume 10, Issue 1 (Special Issue), 2020

Research Article

Copyright $\odot$ RIGEO 2020

To cite this article: Yazıcı, Ö. (2020). Awareness of Hydrography Courses Students on Protection of Freshwater Resources. Review of International Geographical Education (RIGEO), 10, (1), Special Issue, 97-119. Retrieved from http://www.rigeo.org/vol10no1/Number1Spring/RIGEO-V10-N1-5.pdf

DOI: 10.33403 rigeo.634906

Submitted: October 19, 2019

Revised: February 08,2020

Accepted: February 19, 2020

\title{
Awareness of Hydrography Courses Students on Protection of Freshwater Resources*
}

\author{
Öznur YAZICI ${ }^{1}$ \\ Karabük University, Karabük, TURKEY
}

\begin{abstract}
Freshwater, which is present on land, is covered in Hydrography issues within the field of Geography. Hydrography course helps students to understand and interpret the mechanism, importance, distribution, relationship with other earth systems and living life. The importance of freshwater resources, which have been affected by climate changes or climatic irregularities and which have dwindled as a result of the misuse of humans, is increasing day by day. Failed to reach a significant portion of the world's population with clean fresh water, hydroelectric power plants and dams negative impacts on the ecosystem of waste due to contaminated water, biodiversity could not be protected, drought-bound migrations, and wrong water use in agriculture, flood and water damage issues such as waste, water, depending on is one of the major problems facing our world today. The aim of this study is to demonstrate the awareness of the students taking Hydrography courses on the conservation of freshwater resources. To this end, it is designed with the method of qualitative research and as descriptive work. The working group consists of 40 students who take Hydrography courses at Karabük University Faculty of Letters Department of Geography. The participants were selected from Geography Department students whose knowledge of Hydrography course was fresh. The data was collected through an open-ended questionnaire and the findings were analyzed descriptive. According to the findings of the study, the students stated that the distribution of freshwater on the Earth is not stable and adequate, the species in the water is damaged, future investments in water should be planned in advance, and waste should be returned to the economy by recycling instead of pouring into streams and lakes. As a result of the study, it was found that students were aware of problems with freshwater, but believed that their ability to do so individually was limited, and generally expected the solution from the state. According to these results, it may be suggested that it would be beneficial for students to be encouraged to participate in social work practices, Non-Governmental Organizations and projects in which they can take an active role.
\end{abstract}

Keywords

Hydrography, Freshwater, Conservation, Awareness

*A portion of this research was presented in 2. International Congress on Geographical Education (UCEK/ICGE-2019), 3-5 October 2019, Eskişehir-Turkey.

${ }^{1}$ Assist. Prof.: Faculty of Letters, Department of Geography, Karabuk University, Karabuk, Turkey, oznuryazici [at]karabuk.edu.tr ORCID: 0000-0001-7965-643X 
3.8 billion years of water has been found in the Isua rocks in Greenland, which are the oldest rocks in the world, and no other evidence of the existence of water has been found on Earth before this time (Atalık, 2006). Freshwater, which has a long history and is essential for the life of living organisms that make up the biosphere, has a limited potential in terms of its quantity and quality on earth. Besides its vital aspect, waters are also an important source of civilization and development, according to Y1lmaz and Peker (2013). All the civilizations of the past have chosen the environment of water resources as their first settlements, and the societies that have become pioneers in development have been the ones that have been able to use water industrially. People have even given the names of the settlements, regions, the surrounding sea, lakes, streams and waterfalls that they have chosen as a place. Black Sea region, Suluova (Amasya), Gölbaşı (Ankara), Dereli (Giresun), Pınarbaşı (Kastamonu), Sulakyurt (Kırıkkale), Suşehri (Sivas) are some of these.

Based on this importance of water, various estimates and assessments have been made on the total water reserve on earth. According to UNEP (2002, United Nations Environment Programme), the global water reserve is around 1.4 billion $\mathrm{km}^{3}$, of which $97.5 \%$ is salt water in the oceans and the remaining $2.5 \%$ is freshwater present in the Atmosphere, glaciers and groundwater. As we can see, $3 / 4$ of the Earth is covered with water, giving the impression that there is an abundance of water in the world, but the ratio of potable water is only $0.74 \%$ (Akın and Akın, 2007).

In the $20^{\text {th }}$ century world population in the although it has increased threefold compared to the $19^{\text {th }}$ century, it has been determined that the use of water resources has increased sixfold, and it is clear that this situation is not in such a way as to provide equal opportunities (Orhon, Sözen, Üstün, Görgün and Gül, 2002). The lack of freshwater has resulted in a gradual decrease in the rate of clean water per capita worldwide due to the rapid increase in the population. According to the classification according to water assets, it is observed that there is 'water poverty' in countries with an average per capita amount of available water less than $1000 \mathrm{~m}^{3}$ per year, 'water scarcity' in countries with less than $2000 \mathrm{~m}^{3}$, and 'water wealth' in countries with more than $10000 \mathrm{~m}^{3}$ (DPT, 2007) (State Planning Organization). In our country, which had a population of approximately 79 million in 2016, the water potential per capita was measured as $2962 \mathrm{~m}^{3}$ and the availability of usable water per capita was measured as $1418 \mathrm{~m}^{3}$ and the amount of water used was measured as $572 \mathrm{~m}^{3}$ (TMMOB, 2017). Based on these data, it is seen that our country is not a water-rich country in terms of available water potential and is experiencing water scarcity.

Part of Turkey's land is humid and part is under semi-arid conditions. Therefore, in places where the climate is unfavorable and water capacity is insufficient, solutions are sought for irrigation; regional development projects such as the Konya Plain Project (KPP), the Southeastern Anatolia Project (SAP) and the Eastern Anatolia Project (EAP) are being implemented. Like irrigation, the supply of drinking water is also among the major problems. New drinking water resources (Melen River to Istanbul; Kizılırmak and Gerede Stream to Ankara) are being transferred to big cities whose population has increased especially with migrations. Can, Etemoğlu and Avcı (2002) count the other 
solutions used to solve the water shortage as a thrifty and measured water consumption, storage and utilization of rain water, removal of salt from sea water or low-salt ground water.

Today, the struggle to have clean rivers is a common struggle, especially in urban centers (DC Commission on the Arts and Humanities, 2012). In addition, Hydroelectric Power Plants (HPP) built on rivers are described as 'environmentally friendly' according to electricity generation models based on energy sources such as nuclear and coal, but have negative effects on nature (Şengül, 2013). Flooded mainly endemic species, plant and animal ecosystems, agricultural areas, settlements, archaeological and historical sites are among the values damaged by HPP.

The term 'water footprint' was introduced to the literature by Hoekstra (2008) to refer to the amount of freshwater resources used in production and consumption. In parallel with the increase in population in Turkey and in the world, both individually and socially, the water footprint needs to be reduced. In light of various predictions made based on data, the world's water presence is under great threat on both national and international platforms. Y1lmaz and Peker (2013) think that conflicts and wars on the energy resources axis until now will be replaced by water resources wars, which may be much more violent and ungodly. Because, as it is known, the public domain of countries water resources cannot be produced and reproduced; they are limited natural resources (Volkan and Boz, 2006). Therefore, water sustainability must be ensured without creating an undesirable effect on the hydraulic system and without endangering the water usage requirements of future generations (Aytuğ, 2014). In our country and in the world, the way to ensure first vital and then social and economic sustainability is to protect water resources against pollution and to implement qualified water management. Çakmak, Yıldırım and Aküzüm (2008) according to water management; it involves the planned development, distribution and use of water resources.

Important decisions have been taken by various conferences, conventions, regulations and guidelines planned on a global scale in order to ensure a good water management in a universal sense, to make arrangements for water protection and to attract the attention of the community. Some of the protocols that have many official determined the outcome of the research in chronological order, are given below: The Ramsar Convention (February 2, 1971), Urban Waste Water Treatment Directive (May 21, 1991), Conference on Water and Environment in Dublin (January 26-31, 1992), The Helsinki Convention on the Protection and Use of Transboundary Waters and International Lakes (March 17, 1992), The Drinking Water Directive (November 3, 1998), The Water Framework Directive (October 23, 2000), Governing the Protection of Groundwater Against Pollution Directive (April 7, 2012), Surface Water Quality Management Regulation (November 30, 2012). Other than these; important days such as World Wetlands Day (February 2), World Water Day (March 22), World Saving Day (October 31) were declared and 2003 was accepted as the 'International Year of Freshwater' has been recognized. In addition, water education projects such as 'Water in the Mediterranean', 'Blue Drop' and 'Water Awareness' were carried out. According to Kabaş (2004), 'Water in the Mediterranean' and 'Blue Drop' water education projects are generally considered as a topic within environmental education activities. 
The Water Awareness Project supported by TÜBİTAK is part of the project titled 'Water Awareness: Developing Teaching Materials for Water Education' launched at Dokuz Eylül University (Cappellaro, Ünal Çoban, Akpınar, Yıldız and Ergin, 2011).

Taking steps to develop the consciousness of protecting nature with the measures mentioned above, human beings have begun to realize that natural beings are not unlimited and have severely battered them. "The decline of resources, the increase of needs and the damage to the environment has brought it back to itself as environmental problems" (Gökday1, 1997, p. 69). Environmental education is given for this purpose, but it has not yet been reflected in full attitudes and behaviours everywhere. Yücel, Uslu, Altunkasa, Gürçay and Say (2008), the reasons why environmental awareness is not reflected in attitudes and behaviors; adults despite knowing they ignored environmental problems, economic problems, psychological and social reasons to refrain from responding to, training and exemplary behavior is not enough for behavior change activities is not included in the negative attitudes are to be punished or rewarded for.

The International Geographic Union Commission on Geographic Education shares the vision of the United Nations 2005-2014 United Nations Decade of Education for Sustainable Development (UNDESD) and proposes that the action items put forward should be included in Geography education at all levels and anywhere in the world (IGU CGE, 2007). According to Artvinli (2010), Geography education is a fundamental science in the national sense and is just as important for universal approaches as it is for each country to find itself. In this context, the secondary Geography course curriculum (Ministry of National Education, 2018, p. 11-12) it is observed that there are some general objectives in the program for the protection of nature and natural resources and ensuring sustainability. These are the student's; "To attainment geographical skills within the framework of the human-nature relationship, to relate the basic elements of the universe to life, to comprehend the functioning and change of natural and human systems, to develop awareness of the spatial values belonging to the country and the world starting from the near environment, to attainment awareness of responsibility for the functioning of the ecosystem, to understand the importance of spatial planning, to understand the functioning of natural and human systems in local and global interaction, to understand the importance of harmonizing development processes with nature, to evaluate natural disasters and environmental problems and to develop applications for ways of preventing and taking precautions." Based on this vision, it is clear that the science and education of Geography are of great importance in giving the awareness of protecting all natural resources and water within them.

There are some studies that have already been done for different levels of instruction for the protection of freshwater resources. Some of these are given below. Girgin and Ertürk (2003) evaluated energy-food-water issues in secondary education Geography programs and criticized the presence of repeated issues in the spiral development model. In the textbooks they examined, the researchers state that water subjects often do not go beyond showing the places where water is present and the places it forms, and they stress that the individual perspective of the students becomes difficult and the level of 
social participation sensitivity for the country's problems cannot be reached. Atasoy and Ertürk (2008) worked with 1118 students to measure the environmental knowledge and attitudes of sixth, seventh and eighth grade students. In an achievement test, which included questions about hydrosphere, the students 'cognitive achievement was low and their environmental attitudes were not sufficient. Ergin (2008) has prepared a project to develop teaching materials for primary school students to attainment water awareness about water recognition, water pollution and water conservation under the title water awareness. Akpınar, Küçükcankurtaran, Ünal Çoban, Yıldız, Öztürk, Yılmaz, Karadeniz and Ergin (2011); by providing five days and twenty-five hours of water education to Science and Technology course teachers, they investigated the effectiveness of the materials used in water school on teachers' water awareness. According to the results, the water school has had a positive impact on teachers' attitudes towards water use and environmental awareness levels and teachers have stated that this training is essential for everyone. Cappellaro et al. (2011) organized active participation activities under the topics of water recognition, water pollution and water conservation in order to create water awareness in adults. Twenty-five hours of water training is given to adults in practice, unlike informational seminars or conferences that make participants passive. At the end of the study, it was determined that, although limited, participants learned water-related concepts and their behavior and attitudes towards water use were significantly affected in a positive way. Çimen and Yılmaz (2011) investigated the attitudes of university students in different departments towards the environment and their achievements in freshwater ecosystems. The attitudes of the university students towards the environment were determined to be between mid-level and high level. At the end of the study, it was also revealed that the students' success in freshwater ecosystems was high. Damanhouri (2012) examined the level of awareness of the water problem of students in some universities of Jordan, where the water sector has suffered shortages in recent years. At the end of the study, the level of water awareness was determined to be at a poor level. Science field students have more water awareness than humanities. Ganguly and Satpati (2015) suggested that they could do a rain deposition activity for secondary students to learn water saving at school. The researchers believe that students will be able to evaluate this accumulated water in the garden they will design on the roof, and that during hot periods it can have an air conditioning effect on the school building and increase the hydrological cycle. Aydoğdu and Çakır (2016) investigated the attitudes and awareness of secondary school students about using water, and the awareness levels of female students and students with university-graduate parents were significantly higher. De Miranda Coelho, Gouveia, de Souza, Milfont and Barros (2016) conducted research that contributed to the recognition of feelings towards water consumption. The study, conducted with university students in Brazil, found participants were both more likely to have negative feelings about water waste and engage in water conservation activities. Karataş and Karataş (2016) have demonstrated the importance of environmental education as a solution tool for preventing water pollution. Seehamat, Sanrattana and Tungkasamit (2016), in their study aimed at raising $6^{\text {th }}$ grade students' awareness of water resources management, they determined that there were significant differences between pre-test and final tests. There was no significant difference in the comprehension and awareness averages of the students after 
application of water resources management in irrigated and non-irrigated areas. Zor and Dervişoğlu (2017) examined responsibility-based factors that influence secondary students' tendency to conserve freshwater resources, and found that personal norms and ability perception are strong factors. As students become aware of their role in the decline of freshwater resources and what they can do to protect those resources, their tendency to take action also increases.

\section{Purpose of the Study}

As the source of life, the conservation awareness of freshwater, which needs to be considered in the context of Conservation Geography, is a subject that requires great sensitivity. This sensitivity must be imparted to the whole society. For example, CorralVerdugo (2002) states that individuals' awareness levels of water use have an effect on water conservation. As explained in the introduction, previous studies have dealt with issues such as freshwater inadequacy and pollution, mostly in environmental issues, but very few articles have been studied within the scope of the Geography course. Deficiencies in the amount and quality of water, which are among the first problems of 'World Geography', a significant part of which is shaped by 'water', are dealt with within the Geography field covering Hydrography (Water Geography). Therefore, research and development of the knowledge, perception and awareness of the Department of Geography students on freshwater is of great importance. The aim of this study is to demonstrate the awareness of the students of the Department of Geography who have knowledge of Hydrography about the conservation of freshwater resources. 'How are the students of the Department of Geography aware of the conservation of freshwater resources?' In order to answer the question, the following sub-research questions were answered. These research questions are also included in the survey form, which is the data collection tool of the study:

1. What are the students' thoughts on the importance of the existence of water on Earth in terms of its relationship with natural systems and human beings?

2. According to the students, is the distribution of freshwater resources according to the land parts of the Earth and the population balanced and sufficient?

3. Do the students find the water presence sufficient in Turkey's soil, which contains regions under the influence of humid and semi-arid climatic conditions?

4. How do students define the phrase 'water resources management'?

5. According to the students, what is the most important problem with the presence of freshwater on Earth?

6. In terms of sustainability, what needs to be done as a priority for wetlands conservation, according to students?

\section{Methodology}

\section{Research Design}

The research is designed in accordance with the qualitative research approach and has a descriptive design. Qualitative research models focus on words rather than numbers, and are a type of research that interprets situations to make sense of what people do in everyday life, observing the world in its natural environment (Walia, 2015, 
p. 3). According to Başol (2008), "Qualitative research provides an opportunity to see with all its reality the events, facts and situations that surround us in the world we live in." Qualitative researchers, working mostly with a small number of individuals, collect data in a natural environment sensitive to the groups and places of people they address in order to study a problem, and reach conclusions by leveraging data analysis that creates inductive themes (Creswell, 2007, p. 37). It is of great importance to raise awareness of protecting the low freshwater reserve, which is one of the most important global problems in today's world. In this context, it was decided that qualitative research method is the most appropriate research method for this research, which aims to define and interpret the views of the students of the Department of Geography who have taken Hydrography courses, as well as to determine the level of awareness. The participants were evaluated to provide a point of view based on their knowledge, belief, experience, perception, behavior and attitudes. Descriptive research used in the design of the study is done with the aim of explaining events and situations in detail by systematically answering what and how questions (Başol, 2008). Although more depiction is made in the qualitative descriptive approach than interpretation, this does not mean that the approach lacks interpretive efforts or is intended for a neutral portrayal of reality (Seixas, Smith and Mitton, 2018, p. 779). In this study, using qualitative descriptive design, the students of the Department of Geography attempted to portray the importance of freshwater, its scarcity and the awareness of the need for its protection in a way that would enable all readers to understand easily. Nevertheless, the participants also shared their own life experiences in the open-ended questions in the questionnaires, for example, talking about documentary videos they watched and were influenced by, and trying to make sense of these experiences, providing deeper data beyond the description.

\section{Working Group}

The universe of the research consists of the students of the Department of Geography who have taken Hydrography courses in the curriculum. The sample of the study was forty volunteer students who took Hydrography courses in the fall and spring semesters of the 2018-2019 academic year at Karabük University Faculty of Letters Department of Geography. Sampling was used to determine the sample. In contrast to incidental studies that present a cross-section of different groups, particularly of age, resume and cultures, purposeful sampling focuses on people with specific characteristics that may better help relevant research (Smith, Musa and Alkassim, 2016, p. 2-3). In other words, in this type of sampling, "The researcher selects the participant according to the needs of the research" (Morse, 1991, p. 129). In this study, criterion sampling from subgroups of purposeful sampling was used. According to Patton (2001, p. 238) criterion sampling requires the selection of states or persons who meet some important predetermined criteria. In this study, it is assumed that the data obtained from a selected group with preliminary or detailed knowledge of the subject being investigated may be more efficient by choosing criteria sampling. It is envisaged that a group that will be completely or partially unfamiliar with the subject may not be able to provide an adequate assessment. Having taken the Hydrography course among the students of the Department of Geography, which is thought to represent the research subject in the 
most appropriate way by filtering and interpreting the information they received about freshwater, and being fresh in the information has formed the conditions of the criterion sampling. Assuming that some of the information and the emphasis in the courses may have been erased from memory, third and fourth graders who had taken Hydrography in previous years were not included in the study. For this reason, the group of students participating in the study was deliberately selected at the second grade level, and the students of the daytime formal education (primary education-daytime courses) and evening formal education (secondary education-evening courses), which were opened for employees in general, were mixed.

\section{Data Collection Tools}

In this study, which focused on the phenomenon of freshwater conservation awareness, a questionnaire consisting of open-ended questions was used to help students express themselves more easily in writing and to gather more detailed data. According to Popping (2015, p. 5), open-ended questions must be specific in order to obtain meaningful and interpretable data, the question must be formulated in a neutral manner, and also invite for an answer. Also, open-ended questions are useful when the research topic is not meant to be restricted and new titles are expected to emerge (Züll, 2016 , p. 2). In order to avoid limiting the questions used in this study, it was deemed appropriate to use an open-ended questionnaire. During the process of creating the survey questions, a detailed survey of the literature was initially conducted using the keywords of the study. At first, eight questions were designed to contribute to the elimination of deficiencies in the literature. Expert opinion was taken to assess whether the open-ended survey questions were fit for purpose. In line with the recommendations of two Geography education experts, two Physical Geography field experts and one education science field expert, two questions were drawn up and final arrangements were made and the form was made ready for application. These two questions are aimed at 'How the topics of Hydrography contribute to the student's perspective' and 'Policies that can be followed on transboundary streams', and are not directly related to the purpose of the study. Then, forty Geography Department students were asked six openended questions through the questionnaire. The protection of fresh water about their awareness of students' thoughts, comments identify similarities and differences between the survey during the implementation phase, a period of approximately twenty minutes are given. A few students have used it for a slightly longer period of time.

\section{Data Analysis}

Descriptive analysis technique was used to analyze the data obtained from openended survey forms. According to Creswell (2007, p. 148), data analysis in qualitative research includes; preparation and arrangement of data, coding and downloading of data into themes, and finally, representation of data with tables and figures. According to the researcher, these are the core elements of qualitative data analysis. For this purpose, first of all, the participants were given short names and the data related to the articles were written and made into a breakdown. In the first phase, conceptual categories and themes were created by marking student sentences for articles for coding. After the completion of this process by the researcher, consistency and reliability were checked by asking 
another field expert to make a comparison. The reliability of research, by Miles and Huberman (1994, p. 64) Reliability=Consensus/ (Consensus+ Dissensus) is calculated with the formula. Given that the expected reliability is achieved when the coding scheme is $90 \%$ and above depending on the size, it is accepted that the $91 \%$ rate achieved in this research is sufficient. The findings, which were defined after processing the data, categorizing the coding and determining the themes, were analyzed and interpreted descriptive with direct quotations from the sentences of the students.

\section{Findings}

In this part of the research, the findings of the views of the students of the Department of Geography are given.

Table 1

Student Views on the Importance of Water on Earth in Relation to Natural Systems and Human Beings

\begin{tabular}{|c|c|c|c|}
\hline Code & Student Code & $\mathbf{n}$ & $\%$ \\
\hline It is mandatory for living life. & $\begin{array}{l}\text { S1, S3, S4, S5, S9, S10, S11, } \\
\text { S13, S15, S16, S17, S18, S20, } \\
\text { S24, S29, S32, S33, S36 }\end{array}$ & 18 & 45 \\
\hline $\begin{array}{l}\text { Ocean, sea and land waters, the largest } \\
\text { source of moisture, is the raw material } \\
\text { of rainfall. }\end{array}$ & $\begin{array}{l}\text { S6, S8, S12, S26, S27, S31, S35, } \\
\text { S38 }\end{array}$ & 8 & 20 \\
\hline It is used in agriculture and industry. & S22, S28, S30, S39 & 4 & 10 \\
\hline $\begin{array}{l}\text { It has an effect on the soils, climate, } \\
\text { and soil and plant characteristics of a } \\
\text { region. }\end{array}$ & $\mathrm{S} 2, \mathrm{~S} 19, \mathrm{~S} 23$ & 3 & 7.5 \\
\hline $\begin{array}{l}\text { The waters form various ecosystems } \\
\text { according to their chemical properties. }\end{array}$ & $\mathrm{S} 21, \mathrm{~S} 40$ & 2 & 5 \\
\hline $\begin{array}{l}\text { It is the foundation and raison d'etre of } \\
\text { today's civilizations. }\end{array}$ & S7, S37 & 2 & 5 \\
\hline $\begin{array}{l}\text { It is of great importance both } \\
\text { geographically, geologically and } \\
\text { politically. }\end{array}$ & $\mathrm{S} 25, \mathrm{~S} 34$ & 2 & 5 \\
\hline $\begin{array}{l}\text { Water is of great importance in terms } \\
\text { of hygiene. }\end{array}$ & S14 & 1 & 2.5 \\
\hline TOTAL & 40 & 40 & 100 \\
\hline
\end{tabular}

The specific codes of the Geography Department students about the importance of water on Earth in relation to natural systems and human beings are collected in 8 headings (Table 1). 45\% ( $\mathrm{n}=18)$ in the first place is 'It is mandatory for living life.' Second place was $20 \%(n=8)$ with 'Ocean, sea and land waters, the largest source of moisture, the raw material of rainfall', third place was $10 \%(\mathrm{n}=4)$ with 'It is used in agriculture and industry', fourth place was $7.5 \%(n=3)$ with 'It has an effect on the soil, climate, soil and plant characteristics of a region.' 5, 6 and 7. the following codes, with a ratio of $5 \%(\mathrm{n}=2)$, were 'Waters form various ecosystems according to their chemical properties', 'It is the foundation and raison d'etre of today's civilizations' and 'It is of 
great importance both geographically and politically.' The eighth and final code with $2.5 \%(n=1)$ is 'Water is of great importance in terms of hygiene.'

Direct citations to the article 1:

S3. Without water, the main source of life, neither rainfall nor other living things could exist. S9. Most of the human body is made up of water. It is therefore of vital importance.

S19. Rainfall causes the formation of climates and seasons through temperature and evaporation.

S20. Water is the most important factor that sustains the ecosystem.

S23. The most important external factor that gives shape to the Earth is water. It allows nature to regenerate itself.

S24. It is especially important in drinking water and provincial construction.

Table 2

Students' Opinions on Whether the Distribution of Freshwater Resources According to Land Parts and Population on Earth is Balanced and Adequate

\begin{tabular}{|c|c|c|c|}
\hline Code & Student Code & $\mathbf{n}$ & $\%$ \\
\hline $\begin{array}{l}\text { Although } 3 / 4 \text { of the world is covered by } \\
\text { water, most are salty waters. It is } \\
\text { certainly not evenly distributed. }\end{array}$ & $\begin{array}{l}\text { S1, S3, S9, S11, S13, S14, } \\
\text { S15, S18, S23, S27, S31, S32, } \\
\text { S33, S34, S36, S38, S39 }\end{array}$ & 17 & 42.5 \\
\hline $\begin{array}{l}\text { Because water needs are not sufficient } \\
\text { due to the increasing population, there } \\
\text { may be great problems in the future. }\end{array}$ & $\begin{array}{l}\text { S2, S4, S7, S10, S12, S17, } \\
\text { S19, S20, S22, S29, S30 }\end{array}$ & 11 & 27.5 \\
\hline $\begin{array}{l}\text { No, some parts of the Earth really need } \\
\text { water. }\end{array}$ & $\begin{array}{l}\text { S5, S6, S16, S21, S24, S26, } \\
\text { S37, S40 }\end{array}$ & 8 & 20 \\
\hline $\begin{array}{l}\text { While many regions around the world } \\
\text { are struggling with thirst, some regions } \\
\text { are struggling with water-induced } \\
\text { disasters. }\end{array}$ & S25, S35 & 2 & 5 \\
\hline $\begin{array}{l}\text { It is not balanced, but it is sufficient. } \\
\text { Still, despite the technology, it can't } \\
\text { get enough of it everywhere. }\end{array}$ & S8, S28 & 2 & 5 \\
\hline TOTAL & 40 & 40 & 100 \\
\hline
\end{tabular}

Table 2 shows the codes for whether freshwater resources are balanced and adequate in their distribution according to land parts and population on Earth, and seventeen people with a ratio of $42.5 \%$ ' $3 / 4$ of the world is covered with water, although most are salt waters, certainly not evenly distributed', they replied. The ensuing code 'There may be very large shortages in the future because the water need caused by the everincreasing population is not sufficient' accounts for $27.5 \%(\mathrm{n}=11)$. In the third place with $20 \%(n=8)$ 'No, some regions of the Earth are really in need of water', while in the last two places 'Many regions in the world are struggling with thirst, some regions are struggling with water disasters' and 'It is not balanced, but it is sufficient. Nevertheless, the codes 'Despite the technology, water cannot be adequately delivered everywhere' belong to two students $(5 \%)$. 
Direct citations to the article 2:

S1. No, most of the water is salty. Some countries use freshwater as a threat to one another.

S5. No, for example, while the African continent is struggling with thirst, there is no such shortage in Europe.

S6. No, the Middle East and Africa are in need of water.

S7. Unfortunately, no. It is said that due to the increasing population there will be water wars in the near future.

S21. If we compare a person in Africa to a person in North America, the fact that an African consumes the water that an American consumes in one year in 10 years explains everything.

S24. Some places really lack water. Some countries are rich in water. Our country, on the other hand, is not water-rich, even though it gives water to Cyprus.

Table 3

Students 'Views on the Water Presence of Turkish Soil, Which Includes Regions under the Influence of both Humid and Semi-Arid Climatic Conditions

\begin{tabular}{llcc}
\hline \multicolumn{1}{c}{ Code } & \multicolumn{1}{c}{ Student Code } & n & \% \\
\hline $\begin{array}{l}\text { Because there is so much waste of water in } \\
\text { our country, our water presence is } \\
\text { gradually decreasing. }\end{array}$ & $\begin{array}{l}\text { S1, S3, S4, S7, S10, S12, } \\
\text { S16, S18, S21, S25, S27, } \\
\text { S28, S31, S34, S35, S40 }\end{array}$ & 16 & 40 \\
\hline $\begin{array}{l}\text { Our wetlands are in great danger due to } \\
\text { excessive contamination. }\end{array}$ & $\begin{array}{l}\text { S6, S8, S11, S13, S14, S17, } \\
\text { S22, S24, S26, S29, S36, S38 }\end{array}$ & 12 & 30 \\
\hline $\begin{array}{l}\text { While there was no desert in Turkey until } \\
\text { recently, there has been desertification in }\end{array}$ & S15, S23, S32, S33, S37 & 5 & 12.5 \\
$\begin{array}{l}\text { Konya Karapinar as a result of improper } \\
\text { land use. }\end{array}$ & & & \\
\hline $\begin{array}{l}\text { The emergence of a large number of new } \\
\text { karst sinkholes in Konya every year shows } \\
\begin{array}{l}\text { that the groundwater level is gradually } \\
\text { falling. }\end{array}\end{array}$ & S9, S20, S30, S39 & 4 & 10 \\
\hline $\begin{array}{l}\text { Since the summer is arid in the interior and } \\
\text { Southeastern Anatolia, water is scarce. }\end{array}$ & S2, S19 & 2 & 5 \\
\hline $\begin{array}{l}\text { Our country's water resources are } \\
\text { sufficient for now. }\end{array}$ & S5 & 1 & 2.5 \\
\hline TOTAL & 40 & 40 & 100 \\
\hline
\end{tabular}

In the third article, student views on the existence of water in the territory of Turkey are discussed (Table 3). The prominent codes are combined in six themes, with the top $40 \%(n=16)$ coming from 'Because there is too much water waste in our country, our water presence is gradually decreasing.' $30 \%$ to twelve people 'Our wetlands are in great danger due to excessive pollution', $12.5 \%$ to five people 'Until recently there was no desert in Turkey, there has been desertification in Konya Karapinar as a result of incorrect land use', 10\% to four people 'The emergence of a large number of new plains in Konya every year shows that groundwater level is falling', $5 \%$ to two people. 
Direct citations to the article 3:

S30. The acceleration of the formation of sinkhole due to decreased rainfall is one of the most important indicators of water scarcity.

S38. Our drinking water, which is constantly polluted by waste, will become unusable at this rate. If the actual measurements had been made, they might have already crossed the danger line in many places.

Table 4

Student Views on the Meaning of the Phrase 'Water Resources Management'

\begin{tabular}{llcc}
\hline \multicolumn{1}{c}{ Code } & \multicolumn{1}{c}{ Student Code } & n & \% \\
\hline Correct and conscious use of water & S1, S2, S4, S6, S9, S10, S12, & 18 & 45 \\
resources. & S13, S16, S18, S20, S27, S29, & & \\
& S30, S31, S34, S37, S38 & & \\
\hline Planning future investments in water. & S7, S8, S11, S15, S17, S19, S21, & 16 & 40 \\
& S22, S23, S25, S26, S28, S32, & & \\
& S33, S35, S40 & 5 & 12.5 \\
\hline Ensuring a sustainable quality & S3, S5, S14, S36, S39 & 1 & 2.5 \\
\hline I actually think water rules people. & S24 & 40 & 100 \\
\hline TOTAL & 40 &
\end{tabular}

In Table 4, students were asked for an opinion on the meaning of the phrase 'water resources management.' The responses were treated as 4 codes and the ratios of the first and second rank were very close together. These are: 'Accurate and informed use of water resources' with 45\% ( $\mathrm{n}=18)$ and 'Planning future investments in water' with $40 \%$ $(\mathrm{n}=16)$. The other two items are $12.5 \%(\mathrm{n}=5)$ 'Ensuring a sustainable quality' and $2.5 \%$ $(\mathrm{n}=1)$ 'I think water actually governs people.'

Direct citations to the article 4:

S1. More functional use of waters and prevention of waste.

S3. Ensuring a sustainable quality and use.

S6. To get the most efficiency with the least water and use the water consciously.

S8. Preparation of investment plans for tomorrow. The General Directorate of State Hydraulic Works has undertaken water management in Turkey. In the past, many lakes have been dried up and turned into agricultural areas.

S12. It is the study and examination of how the water resources available can be used and developed in the most accurate way.

S15. While water supplies may seem limitless and Renewable, they may become inadequate due to misuse. Water management means plan and control.

S25. Foresee the problems that may arise in the future related to water and do the measures in advance.

S26. I understand that water resources are deplorable and that precautions must be taken from today.

S37. It's the ability to use water. 
Table 5

Student Views on what is the Most Important Problem with Freshwater Presence on Earth

\begin{tabular}{llcc}
\hline \multicolumn{1}{c}{ Code } & \multicolumn{1}{c}{ Student Code } & n & \% \\
\hline Declining water resources & S1, S4, S8, S10, S12, S14, S17, & 15 & 37.5 \\
& S18, S20, S22, S23, S28, S34, S37, & & \\
& S40 & 11 & 27.5 \\
\hline Water contamination & $\begin{array}{l}\text { S5, S9, S11, S19, S21, S25, S26, } \\
\text { S29, S30, S32, S39 }\end{array}$ & & \\
\hline Damage to aquatic species & S6, S16, S31, S33, S35, S36 & 6 & 15 \\
\hline Improper and excessive irrigation & S2, S7, S15, S27 & 4 & 10 \\
\hline $\begin{array}{l}\text { Melting glaciers with greatest } \\
\text { freshwater potential due to global } \\
\text { climate change }\end{array}$ & S13, S24 & 2 & 5 \\
\hline $\begin{array}{l}\text { Water-borne conflicts, conflicts and } \\
\text { wars between countries }\end{array}$ & S3, S38 & 2 & 5 \\
\hline TOTAL & 40 & 40 & 100 \\
\hline
\end{tabular}

In Table 5, what is the most important problem with the presence of freshwater is investigated. The top place was the code 'Steadily decreasing water resources' $(37.5 \%$, $\mathrm{n}=15)$. Immediately followed by 'Water contamination' $(27.5 \%, \mathrm{n}=11)$. Other important issues that have been voiced; 'Harm aquatic species' $(15 \%, \mathrm{n}=6)$, 'Incorrect and excessive irrigation' $(10 \%, \mathrm{n}=4)$, 'Largest freshwater due to melting glaciers in global climate change that has had the potential' $(5 \%, \mathrm{n}=2)$ and 'Conflicts between countries, conflicts and water-borne that may arise wars' $(5 \%, \mathrm{n}=2)$ as is stated.

Direct citations to the article 5:

S1. I was very impressed by the documentary ' 25 liters' which we focused on in the course.

The world is rapidly drifting into water scarcity.

S7. It's incredibly sad to see Lake Aral dry up because of excessive irrigation.

S9. Unfortunately, by dumping waste, our rivers and lakes are rapidly polluting. The situation is much worse in small surface waters.

S21. Household and factory wastes seriously pollute our drinking and use waters.

S28. With urbanization, water consumption becomes excessive and wasteful, and freshwater decreases.

Table 6

Student Views on What Can Be Done to Protect Wetlands in Terms of Sustainability

\begin{tabular}{llcc}
\hline \multicolumn{1}{c}{ Code } & \multicolumn{1}{c}{ Student Code } & n & \% \\
\hline People need to be conscious. & $\begin{array}{l}\text { S3, S6, S8, S16, } \\
\text { S17, S19, S27, } \\
\text { S37 }\end{array}$ & 8 & 20 \\
& & & \\
\hline $\begin{array}{l}\text { Instead of dumping waste into streams and lakes, it } \\
\text { should recycle it into the economy. }\end{array}$ & $\begin{array}{l}\text { S1, S9, S10, S15, } \\
\text { S18, S26 }\end{array}$ & 6 & 15 \\
\hline $\begin{array}{l}\text { Businesses in the industrial and manufacturing } \\
\text { branches should be subjected to heavy sanctions by } \\
\text { the state on refining and filtering. }\end{array}$ & $\begin{array}{l}\text { S12, S14, S21, } \\
\text { S31, S39 }\end{array}$ & 5 & 12.5 \\
\hline All wetlands should be protected by the state. & S5, S24, S25, S30 & 4 & 10 \\
\hline Drip irrigation must be switched. & S11, S33, S36, & 4 & 10 \\
\hline
\end{tabular}




\begin{tabular}{|c|c|c|c|}
\hline & S38 & & \\
\hline $\begin{array}{l}\text { Quotas should be put in place to prevent excessive } \\
\text { use of freshwater. }\end{array}$ & S28, S32, S34 & 3 & 7.5 \\
\hline The lake must be prevented from drying out. & S2, S23 & 2 & 5 \\
\hline $\begin{array}{l}\text { The Non-Governmental Organizations working on } \\
\text { this issue should be supported. }\end{array}$ & S29, S35 & 2 & 5 \\
\hline Groundwater must be stored to remain clean. & S13 & 1 & 2.5 \\
\hline $\begin{array}{l}\text { New water resources should be sought with the } \\
\text { emerging technology. }\end{array}$ & S22 & 1 & 2.5 \\
\hline $\begin{array}{l}\text { Some lakes should be artificially reinforced with } \\
\text { water. }\end{array}$ & S4 & 1 & 2.5 \\
\hline $\begin{array}{l}\text { For increased humidity and rainfall, plantations or } \\
\text { dams should be made. }\end{array}$ & S20 & 1 & 2.5 \\
\hline $\begin{array}{l}\text { Intensive agriculture should be done more yield from } \\
\text { less area. }\end{array}$ & S7 & 1 & 2.5 \\
\hline $\begin{array}{l}\text { Since dams prevent fish migrations and damage the } \\
\text { ecosystem, solar and wind energy should be diverted. }\end{array}$ & S40 & 1 & 2.5 \\
\hline TOTAL & 40 & 40 & 100 \\
\hline
\end{tabular}

Student views on what can be done to protect wetlands in terms of sustainability have been the most codified question (Table 6). In total of 14 codes, 'People should be conscious' $(20 \%, \mathrm{n}=8)$ took the first place. In second place, $15 \%(\mathrm{n}=6)$ 'Waste spilling into streams and lakes, instead of recycling to the economy', in third place $12.5 \%$ with $(n=5)$ 'Industry and arms production enterprises, should be subject to heavy sanctions by the state on filtration' is. The ensuing 'All wetlands must be protected by the state' and 'Drop irrigation must be passed' codes have the same ratio as $10 \%(n=4)$. Other codes; 'Quota should be placed to prevent excessive use of fresh water' $(\% 7.5, n=3)$, 'Must be prevented from drying of the lake' (5\%, $n=2)$, 'Non-Governmental Organizations (NGOs) should be given support in this thread who has been working in' $(5 \%, \mathrm{n}=2)$, 'Should be stored to keep clean groundwater' $(2.5 \%, \mathrm{n}=1)$, 'The developing technology, together with new sources of water must be sought' $(2.5 \%, \mathrm{n}=1)$, 'Some lakes artificially to supplement water should be made' $(\% 2.5, \mathrm{n}=1)$, 'Or equivalent should be made to increase humidity and rainfall dams' $(2.5 \%, \mathrm{n}=1)$, 'More out of less space efficiency should be achieved by intensive agriculture' $(2.5 \%, \mathrm{n}=1)$ and 'Since dams block fish migrations and damage the ecosystem, solar and wind energy should be diverted' $(2.5 \%, \mathrm{n}=1)$ has been.

Direct citations to the article 6:

S3. People need to be conscious. Those who govern society before the individual should be sensitive and not compromise.

S6. The most beautiful example of this is the Aral Lake. It is nearly dry due to improper irrigation. Education is the best way to raise people's awareness.

S12. The treatment plants must be activated.

S21. By setting up large treatment plants, we can turn Sea and ocean waters into freshwater, such as the examples of Arabia and Australia.

S27. First, we need to educate people and show that the possible consequences of misuse will negatively affect all people. 


\section{Conclusions, Discussion and Recommendations}

Hydrography course covers the formation, properties and importance of water on Earth. In this research, the students of the Department of Geography who took the Hydrography course, based on their knowledge-skills-life and experience, how they understand the importance and management of freshwater waters, how they perceive the problems on earth about freshwater and their awareness of freshwater conservation were tried and the following results were reached:

The greatest importance of the existence of water on Earth for students in terms of its relationship with natural systems and human beings was the expression 'Essential for living life' $(45 \%, \mathrm{n}=18) .8$ students $(20 \%)$ responded to this article 'Ocean, sea and land waters, the greatest source of moisture, the raw material of rainfall', while 4 students $(10 \%)$ responded 'Used in agriculture and industry.' Other responses; 'A region of landforms, climate, soil and plant properties is that it is effective' (\%7.5, $n=3)$, 'Chemical characteristics of the waters according to the various ecosystems they form' $(5 \%, \mathrm{n}=2)$, 'The foundation of today's civilization and this is the reason for its existence' $(5 \%, \mathrm{n}=2)$, 'Both geographical and political terms has great significance in' $(5 \%, \mathrm{n}=2)$, 'Water, is of great importance in terms of hygiene' $(2.5 \%, \mathrm{n}=1)$ are listed as. Evsahibioğlu, Aküzüm and Çakmak (2010), the first of two major policies that have been discussed and raised on a global scale; 'Water is a human right, it should be made available to the citizens as cheaply as possible in line with the principle of public interest' and secondly, 'Water is a human need. Because it is a commercial commodity, the price must be met by the customer in accordance with the market requirements. Water is the most important element that comes after air at every stage of its life. The response of S24 from the students 'Is particularly important in the construction of drinking water and province' is notable. While all sectors are important, there is no doubt that their use in medicine has a distinct value and it appears to affect student perception. Examples of various studies discussing the importance of water resources and the necessity of sustainability are: Girgin and Ertürk (2003), Atalık (2006), Akın and Akın (2007), Ergin (2008), Akpınar et al. (2011), Cappellaro et al. (2011), Çimen and Yılmaz (2011), Damanhouri (2012), Aytuğ (2014), Aydoğdu and Çakır (2016), Karataş and Karataş (2016), Seehamat et al. (2016), Zor and Dervişoğlu (2017) may be given.

In the second article, the student views on whether the distribution of freshwater resources according to land parts and population on the Earth is balanced and adequate. In the first place $3 / 4$ of the world is covered with water, though most are salty waters. It is located in' absolutely not evenly distributed ' $(42.5 \%, \mathrm{n}=17)$. The second one was 'There may be great problems in the future because the water need due to the increasing population is not sufficient' $(27.5 \%, \mathrm{n}=11)$ and the third one was 'No, some parts of the Earth are really in need of water' $(20 \%, n=8)$. The other two codes are 'Many regions in the world are dealing with thirst, while some regions are dealing with water disasters' and 'It is not balanced, but it is sufficient. However, despite the technology, it has an equal ratio of' (5\% to 2 students each). In and out of Turkey in the world, because of irregularities in the topography rainfall and to suppress the uneven distribution of resources the control of resources by region, with the holistic watershed approach to 
water resources on the basis of long-term planning, instead of regional, independent and short-term projects-making (DPT, 2001), such as the presence of water affects. Although water transport can be carried out at close distances, this is not possible anywhere and under all conditions. It is worth highlighting the S21 response to this article, 'If we compare a person in Africa with a person in North America, the fact that an African consumes the water that an American consumes in one year in 10 years explains everything.' By reconciling the inequality of opportunity in the world with the influence of different geographies, the students have made sense of the unlimited use of freshwater assets by the citizens of superpowers in the world as a luxury and an extravagant advantage. In fact, there are significant desert areas in the United States, but these arid regions do not have many populations. Considering that countries with an annual amount of water per capita of $10,000 \mathrm{~m}^{3}$ and above are water-rich, Canada is at its peak with $92,000 \mathrm{~m}^{3}$ per capita, while Kuwait is among the most water-poor countries with $8 \mathrm{~m}^{3}$ (The Worldwatch Institute, 2004).

When the student views on the water presence of the Turkish territory were evaluated, it was observed that the code 'Water presence is gradually decreasing because there is too much water waste in our country' $(40 \%, \mathrm{n}=16)$ took the first place. This is followed by 'Our wetlands are in great danger due to excessive pollution' $(30 \%$, $\mathrm{n}=12$ ) and 'While there was no desert in Turkey until recently, there has been desertification in Konya Karapinar as a result of incorrect land use' $(12.5 \%, \mathrm{n}=5)$. Other codes for this article; 'Every year in Konya the emergence of many new sinkhole, shows that the groundwater level will be gradually reduced' were $(10 \%, n=4)$, 'Central and Southeastern Anatolia through the summers, there is scarcity of water' $(5 \%, \mathrm{n}=2)$ and 'Our country's water resources is sufficient for now' $(2.5 \%, \mathrm{n}=1)$ are listed as. The views of the students of the Department of Geography on the state of our country's water presence shows that they are aware that we are a country with scarcity of water. Damanhouri (2012) found that students at some universities in Jordan, where water is scarce, have poor awareness of the water problem and that science students have higher awareness than those in humanities. The area of Geography includes both science and Social Sciences, and the Hydrography branch is within the scope of science. This research shows, in part, similarities with Damanhouri's study results. The emphasis of the students on Konya sinkholes and the dunes formed in Konya Karapinar shows that they are aware of the problem of water scarcity. According to Y1ldız and Özbay (2011); the failure to develop superficial irrigation projects in the Konya Plain quickly led the people of the region to groundwater, and as a result of the opening of tens of thousands of unlicensed wells, the groundwater table fell rapidly and caused the formation of sinkholes. The most striking statement on this article came from S38: 'Our drinking water, which is constantly polluted by waste, will become unusable at this rate. If the actual measurements had been made, they might have already crossed the danger line in many places.' The state waterworks performs water quality measurements only at major sources where dam lakes are located, and this practice is far from managing all the country's resources (Orhon et al., 2002). Therefore, it is understood that students have a preconception against assessments made for water quality measurement and do not trust the results announced. In order to eliminate this negative perception, sensitive water 
quality measurements should be made more frequently and more widely by public and private institutions, and conservation action plans should be initiated by taking emergency measures where critical values are exceeded. Population growth, urbanization, industrial and domestic waste, pesticides and fertilizers are among the primary water pollutants. In order for watersheds to be protected, they must be located in places far from settlements. According to the opinions of the students coming to the third article, the students of the Department of Geography who have taken Hydrography are aware of the water problems in Turkey.

When the codes expressed by the students on the meaning of the expression 'water resources management' are examined, it is seen that the first two words in the order are in close proportions. These were 'Accurate and informed use of water resources' (45\%, $\mathrm{n}=18)$ and 'Planning of future investments in water' $(40 \%, \mathrm{n}=16)$. The other themes are; 'Ensuring a sustainable quality' $(12.5 \%, \mathrm{n}=5)$ and 'I actually think water governs people' $(2.5 \%, \mathrm{n}=1)$. Holistic water resources management; economic and social welfare without compromising the sustainability of vital ecosystems a fair approach to maximize water, land and related resources is defined as the process of coordinated development and management (TAC, 2000) (Global Water Partnership Technical Advisory Committee). Evsahibioğlu et al. (2010); modern methods for good water management and efficient water use (re-use, water purification, rain water collection, inter-basin and transboundary water transfers, such as alternative irrigation practices) should be used recommends. The definitions of the students are brief and concise, but meet these definitions. For example, according to S15 'water management' means plan and supervision. The meaning of the word 'management' in his mind is to guide facts and events by making decisions in a disciplined, authoritative, effective and efficient way. Based on their own life experiences such as money, machinery and school management, almost all students see water management as an important responsibility. In general, students have the perception that this responsibility and investments must be coordinated by the state. In this article one the code from the S24 'I actually think water governs people' has created a cyclical cause-and-effect relationship and a dilemma. In this response, it is understood that people have lived or tried to adapt to water throughout history because it is essential for life. Indeed, past civilizations have always been established near water, and all of the countries that are water-poor today are underdeveloped countries.

In the fifth article, where the most important question regarding the existence of freshwater is questioned, the code 'Gradually decreasing water resources' (37.5\%) with 15 students was the most response. The closest code to this, 'Water contamination' $(\mathrm{n}=11)$, has a $27.5 \%$ share. With 6 people 'Harm aquatic species' (\%15), 4 person 'Wrong and excessive irrigation' (\%10), 2 person 'With the largest freshwater due to melting glaciers in global climate change potential that has had' $(5 \%)$ and 'Disputes between countries, conflicts and water-borne that may arise wars' (\%5), gives rise to other important issues that the students expressed. There are many problems associated with water on the Earth, and unfortunately, most of them are catastrophic because they affect large masses. All of the dangers listed by the students concern all natural beings on earth. According to Doğanay (2000), the main purpose of all geographical research is 
to investigate the human-neutralization of the difficulties caused by environmental factors. Ergin, Akpınar, Küçükcankurtaran and Ünal Çoban (2009) highlighted the decline of water resources as well as their rapid contamination. Aydoğdu and Çakır (2016) emphasize that depletion of water resources is a major threat. Erten (2006) attributes the problems such as water pollution, climate changes, damage to plant and animal species to causes such as extravagance, inability to adequately evaluate waste, lack of education and consumer society. It is also important for the students to express the existing problems and to be able to come up with solutions for how to overcome them.

Based on the views in article five, students taking Hydrography courses can be said to have a high level of awareness of what is happening to water problems in the world. S1 has stated that the National Geographic Turkey documentary '25 liters' which we are focusing on in the context of this course has affected him very much and he has realized that the world is rapidly being dragged into water scarcity. The documentary describes the necessity to live with 25 liters of water every day and describes the water crisis that may arise especially in crowded cities. The proportion of students who have the perception that access to Freshwater may be difficult in the near future is high (37.5\%). S7 also emphasized that Aral, one of the largest lakes in the world, has shrunk 17 times since 1960 and expressed its sadness with the words 'It is incredibly sad to see that Aral Lake has dried up due to excessive irrigation.' In particular, students of the Department of Geography will be able to draw much attention to these concrete examples and make a great contribution to informing, stimulating and mass awareness of their environment and future students.

In the sixth and final article, in which the most themes emerged in the research with fourteen chapters, student views were taken on what can be done about wetland conservation in terms of sustainability. Eight students in the first row with 'People are made aware of' (20\%), followed with six students in the 'Waste spilling into streams and lakes, instead of recycling to the economy' (15\%) and five with 'industry and arms production enterprises, should be subject to heavy sanctions by the state on filtration of' $(12.5 \%)$ is. The following two statements have the same ratio: 'All wetlands should be protected by the state' and 'Drip irrigation' (10\%, four persons). Eight remaining themes; three other people with a 'Quota should be placed to prevent excessive use of fresh water' $(7.5 \%)$, with two 'Should be prevented from drying of the lake' $(5 \%)$ and Non-Governmental Organizations should be given support in this thread who has been working' (5\%) with only one person 'Should be stored to keep clean groundwater' (by $2.5 \%$ ), 'Developing technology together with new sources of water must be sought' (by $2.5 \%)$, 'Some lakes should be made to artificially supplement water' (2.5\%), 'Or equivalent should be made to increase humidity and rainfall dams' $(2.5 \%)$, It is listed as' intensive agriculture should be made more yield than less area' $(2.5 \%)$ and 'Since dams prevent fish migrations and damage the ecosystem, solar and wind energy should be directed' $(2.5 \%)$.

As we can see, the theme that most students are involved in has been the belief that people can be raised awareness through education. Apart from this, the suggestion that three students 'Quotas should be put in place to prevent excessive use of freshwater 
water' is noteworthy. Because these students have the belief that consciousness may not be sufficient in society in the prevention of water supply under the present conditions, therefore, 'Limiting water to be offered to people' could be a much better solution. In addition to providing information on the protection of freshwater resources at different levels of education, adult education is also sometimes carried out in the world and in Turkey. For example, the Georgia Environmental Protection Division Watershed Protection Branch in United States (Georgia Environmental Protection Division Watershed Protection Branch, 2007), as well as conservation for students of both school programs are designed to promote public awareness and public education programs. Protection awareness building programs are also available for water systems employees. Cappellaro et al. (2011) found that active participation can make positive changes in applied behaviors and attitudes in order to create water awareness in adults.

In order to teach water saving, Ganguly and Satpati (2015) state that rain deposition activity can be done with secondary students, that the accumulated water can be used in a garden to be designed on the roof, that water can have an air conditioning effect in the school building during the summer period and will positively affect the hydrological cycle six some participants in the article expressed the need to support NonGovernmental Organizations. According to Cappellaro et al., (2011) the most active in environmental education for adults are voluntary environmental associations and foundations. These organizations, through their various activities, directly or indirectly ensure the environment of education for the environment and the increase of the awareness and awareness of the environment of adults. When the students 'Responses are looked at, it is seen that they count the solutions they expect from the state, not the individual ones in general. They seem to have forgotten that society is made up of individuals, are hesitant about how they can actively take action and do not feel fully adequate. Even when they wrote that NGOs should be supported, they used statements that excluded them.

This perception of his sophomore students seems to be due to the fact that they have not yet acquired a geographer identity. These young people, who can actively contribute to the protection of the environment and all its natural elements, are thought to be able to develop their thoughts and beliefs about the best performance of their social role through their attainment in more advanced grades.

Based on these results, the following recommendations may be made at the end of the study:

- A continuation of this research, students of the Department of Geography who have not taken Hydrography courses can be compared by investigating their awareness of freshwater conservation. Thus, it can be determined whether hydrographic knowledge contributes to conservation awareness.

- In order to internalize freshwater conservation awareness and turn to behavior, the independent planning of water trainings from environmental protection trainings can provide greater attention. 
- Publicity and information about the enlightenment of society can be made through the media and the internet.

- University students and teacher candidates in particular may be encouraged to participate in the activities of related NGOs.

- Water education for students at all levels of education towards applied studies, dam visits such as field studies, computer on city water supply and distribution system a visit to the historic fountain in the vicinity, rain and snow water harvesting of field experts to be invited to the school, water footprint, water pollution can cause health problems, waste water recycling, and the types of dam structures, flood prevention, drought-bound migrations, projects and assignments on topics such as the benefits of spas and health resorts that can be given.

- Farmers can be trained to choose planting and farming methods where they can do more irrigation with less water.

- For the effective use of water, mobilization can be initiated by the country.

- Integrated water resources management can be developed in a coordinated and systematic way.

\section{References}

Akın, M. \& Akın, G. (2007). Importance of water, water potential in Turkey, water basins and water pollution. Ankara University the Journal of the Faculty of Languages and HistoryGeography, 47(2), 105-118.

Akpınar, E., Küçükcankurtaran, E., Ünal Çoban, G., Yıldız, E., Öztürk, C., Yılmaz, Y., Ergin, Ö. (2011). Water school: An application for creating water awareness of Science teachers. National Education, 40(192), 174-192.

Artvinli, E. \& Kaya, N. (2010). 1992 International Charter on Geographical Education and its reflections in Turkey. Marmara Geographical Review, 22, 93-127.

Atal1k, A. (2006). Effects of global warming on water resources and agriculture. Science and Utopia, 139, 18-21.

Atasoy, E. \& Ertürk, H. (2008). A field study about environmental knowledge and attitudes of elementary school students. Erzincan University Journal of Education Faculty, 10(1), $105-122$.

Aydoğdu, B. \& Çakır, A. (2016). An investigation of middle school students' attitudes and awareness of water use. International Journal of Environmental \& Science Education, 11(16), 9520-9536.

Aytuğ, H. K. (2014). Harmonisation of Turkey to environmental policies of the European Union in terms of sustainable water use. The International Journal of Economic and Social Research, 10(2), 1-18.

Başol, G. (2008). Scientific research process and method. In O. Kılıç, M. Cinoğlu (Eds.), Scientific Research Methods (pp. 113-143). İstanbul: Lisans Publishing.

Çakmak, B., Yıldırım, M. \& Aküzüm, T. (2008). Agricultural irrigation management in Turkey, problems and solutions. UCTEA Chamber of Civil Engineers II. Water Policy Congress, Volume I, p. 215-224, Ankara. 
Can, M., Etemoğlu, A. B. \& Avc1, A. (2002). Technical and economic analysis of desalination processes. Uludăg University Journal of the Faculty of Engineering and Architecture, 7(1), 147-160.

Cappellaro, E., Ünal Çoban, G., Akpınar, E., Yıldız, E. \& Ergin, Ö. (2011). An example of applied environmental education for adults: Water awareness education. Journal of Turkish Science Education, 8(2), 157-173.

Çimen, O. \& Y1lmaz, M. (2011). University students' perception levels of basic concepts related to freshwater ecosystems. Journal of Bayburt Education Faculty, 6(I-II), s. 40-48.

Corral-Verdugo, V. (2002). A structural model of pro-environmental competency. Environment \& Behavior, 34, 531-549.

Creswell, J. W. (2007). Qualitative inquiry \& research design, Choosing among five approaches ( $2^{\text {nd }}$ Edition). Thousand Oaks, London, New Delhi: Sage Publications.

Damanhouri, M. S. (2012). Level of water awareness at some Jordanian universities' students. Journal of Social Sciences, 8(3), 454-458.

DC Commission on the Arts \& Humanities (2012). Reclaiming the edge, urban waterways \& civic engagement. Retrieved from https://anacostia.si.edu/Resources/Reclaiming-theEdge.pdf

de Miranda Coelho, J. A. P., Gouveia, V. V., de Souza, G. H. S., Milfont, T. L., \& Barros, B. N. R. (2016). Emotions toward water consumption: Conservation and wastage. Revista Latinoamericana de Psicología, 48, 117-126.

Doğanay, H. (2000). Introduction to Geography. Konya: Çizgi Bookstore.

DPT (2001). $8^{\text {th }}$ five-year development plan. Watershed use and management special expert commission report. DPT: 2555- ÖIKK: 571, Ankara.

DPT (2007). Use and management of soil and water resources. $9^{\text {th }}$ development plan Specialized commission report, State Planning Organization (Devlet Plânlama Teşkilatı), Ankara.

Ergin, Ö. (2008). An educational project for 'water awareness'. In UCTEA 2. Water Policy Congress Proceeding Book (pp. 531-540). Ankara: Mattek Publication.

Ergin, Ö.; Akpınar, E., Küçükcankurtaran, E. \& Ünal Çoban, G. (2009). Water awareness: A teaching material for water education. Project Number: 107K291.

Erten, S. (2006). Psychological and sociological barriers that may arise in energy saving behavior. 25. Energy Efficiency Conference (February 23-24, 2006). Ankara: Hacettepe University. Publication of the Directorate General of Electrical Affairs Survey Administration (Book).

Etikan, I., Musa, S. A., \& Alkassim, R. S. (2016). Comparison of convenience sampling and purposive sampling. American Journal of Theoretical and Applied Statistics, 5(1), 1-4.

Evsahibioğlu, A. N., Aküzüm, T. \& Çakmak, B. (2010). Water management, water use strategies and transboundary waters. Turkey Agricultural Engineering VII. Technical Congress (January 11-15, 2010), National Library Conference Hall, Ankara.

Ganguly, L. \& Satpati, L. (2015). Awareness of water conservation among school students and ensuring their participation in water harvesting. International Journal of Innovative Research in Technology (IJIRT), 2(7), 792-794. 
Georgia Environmental Protection Division - Watershed Protection Branch (2007). Water Conservation Education Programs, EPD Guidance Document. Retrieved from https://www1.gadnr.org/cws/Documents/Conservation_Education.pdf

Girgin, M. \& Ertürk, M. (2003). Evaluation of energy, food, and water subjects in programmes of secondary school Geography education. Journal of Muğla University Social Sciences Institute, 10, 31-40.

Gökday1, İ. (1997). The future of the environment, approaches and policies. Ankara: Turkey Environment Foundation Publications.

Hoekstra, A. Y. (2008). The water footprint of food. In J. Förare (Ed.), Water for food, The Swedish Research Council for Environment, Agricultural Sciences and Spatial Planning (Formas) (pp. 49-60). Stockholm, Sweden: The Swedisch Research Council for Environment.

IGU CGE (2007) (International Geographical Union Commission on Geographical Education). Lucerne Declaration on Geographical Education for Sustainable Development (Turkish). Retrieved from http://www.igu-cge.org/wp-content/uploads/2018/02/turkish.pdf

Kabaş, D. (2004). Information levels of woman about environment problems and environment education (Unpublished Master Thesis). Gazi University, Institute of Educational Sciences, Department of Family Economics and Nutrition, Ankara.

Karataş, A. \& Karataş, E. (2016). Environmental education as a solution tool for the prevention of water pollution. Journal of Survey in Fisheries Sciences, 3(1), 61- 70.

Miles, M. B. \& Huberman, A. M. (1994). Qualitative data analysis an expanded sourcebook. Thousand Oaks, CA, US: Sage Publications.

Ministry of National Education (2018). Secondary Education Geography Course (9th, 10th, 11 th, and 12th grades) Curriculum.

Morse, J. (1991). Strategies for sampling. In J. M. Morse (Ed.), Qualitative Nursing Research: A Contemporary Dialogue (pp. 127-146). Newbury Park, CA: Sage Publications.

Orhon, D., Sözen, S., Üstün, B., Görgün, E. \& Gül, Ö. (2002). Water management and sustainable development preliminary report, Vision 2023: Science and Technology Strategies Technology Foresight Project Environment and Sustainable Development Panel.

Patton, M. Q. (2001). Qualitative research and evaluation methods ( $2^{\text {nd }}$ Edition). Thousand Oaks, CA: Sage Publications.

Popping, R. (2015). Analyzing open-ended questions by means of text analysis procedures. Bulletin de Méthodologie Sociologique, 128, 1, 23-39. DOI: 10.1177/0759106315597389.

Seehamat, L., Sanrattana, U. \& Tungkasamit, A. (2016). The developing on awareness of water resources management of grade 6 students in Namphong Sub-Basin. International Education Studies, 9(5), 156-165.

Seixas, B. V., Smith, N. \& Mitton, C. (2018). The qualitative descriptive approach in international comparative studies: Using online qualitative surveys. International Journal of Health Policy and Management, 7(9), 778-781.

Şengül, M. (2013). Turkey's water policies and fury of the villagers. Policies and Issues: Global to Local Panel Papers Book, Nevşehir Üniversitesi Nevşehir University Faculty 
of Economics and Administrative Sciences Department of Public Administration Management of Water Resources, pp. 29-41.

TAC (2000). (Global Water Partnership Technical Advisory Committee). Integrated water resources management. TAC Background Pap, 4, Stockholm, p.71.

The Worldwatch Institute (2004). State of the World 2004: Special focus: The consumer society. Washington: W. W. Norton \& Company Inc.

TMMOB (2017). (UCTEA-The Union of Chambers of Turkish Engineers and Architects). The source of life is water. The Chamber of Geology Engineers, Konya Branch. Retrieved from https://www.jmo.org.tr/genel/bizden_detay.php?kod=9656\&tipi=2\&sube=8\#.XYohkfAzYkI

UNEP (2002) (The United Nations Environment Programme). Vital water graphics: An overview of the state of the world's fresh and marine waters. Nairobi.

Volkan, F. \& Boz, B. (2006). Findings and recommendations for water resources development policies in Turkey. In UCTEA Water Policies Congress Proceeding Book (pp. 150-155). Ankara: UCTEA Chamber of Civil Engineers Ankara Branch.

Walia, R. (2015). A saga of qualitative research. Sociology and Criminology, 3(2), 1-3. DOI: $10.4172 / 2375-4435.1000124$.

Yıldız, D. \& Özbay, Ö. (2011). Kal(kın)dırma kuvveti olarak su, GAP-KOP-DAP. Retrieved from http://www.topraksuenerji.com/Report_GAP_KNIGHT_DAP_17_Agustus_2011.pdf

Yilmaz, M. L. \& Peker, H. S. (2013). A possible jeopardy of water resources in terms of Turkey's economic and political context: Water conflicts. Çankırı Karatekin University Journal of the Faculty of Economics and Administrative Sciences, 3(1), 57-74.

Yücel, M., Uslu, C., Altunkasa, F., Gürçay, S. S. \& Say, P. N. (2008). Determining the environmental sensitivity of the people in Adana and developing measures to increase this sensitivity, Adana Urban Issues Symposium, 363-382, UCTEA.

Zor, S. \& Dervişoğlu, S. (2017). Factors effecting students' tendencies to protect freshwater resources. Online Science Education Journal, 1(1), 1-10.

Züll, C. (2016). Open-ended questions. GESIS Survey Guidelines. Mannheim, Germany: GESIS - Leibniz Institute for the Social Sciences. doi: 10.15465/gesis-sg_en_002.

\section{Biographical Statement}

Öznur YAZICI studies on Physical Geography Department and is interested in Physical Geography education, natural and cultural heritage, Conservation Geography, and Geography teaching with art. She works at Karabük University, Faculty of Letters, and Department of Geography. 